\title{
Biliary sphincter balloon dilation: Who, when and how?
}

\author{
K Huibregtse MD PhD
}

\begin{abstract}
K Huibregtse. Biliary sphincter balloon dilation: Who, when and how? Can J Gastroenterol 1999;13(6):499-500. Biliary sphincter balloon dilation for biliary stone removal was introduced in 1983. In the early 1990s, several groups studied this technique further. The success rate of stone removal is comparable with that of endoscopic sphincterotomy in patients with fewer than three stones that are less then $1 \mathrm{~cm}$ in diameter. Fewer complications after balloon dilation than after endoscopic sphincterotomy have been noted in most studies. One study, however, showed a higher incidence of pancreatitis and, in particular, severe pancreatitis. Therefore, there is still some reluctance among endoscopists to promote balloon dilation as a routine first choice treatment. The technique, however, is accepted as the treatment of choice in patients with a bleeding tendency and those in whom the local anatomy is associated with an increased risk of complications with endoscopic sphincterotomy, such as patients with periampullary diverticula or Billroth II gastrectomy.
\end{abstract}

Key Words: Biliary sphincter balloon dilation; Endoscopic sphincterotomy; Endoscopy

\section{Dilatation par ballonnet du sphincter biliaire : Qui, quand et comment?}

RÉSUMÉ : La dilatation par ballonnet du sphincter biliaire pour extraction des calculs biliaires a fait son apparition en 1983. Au début des années 1990, plusieurs groupes ont étudié cette technique plus à fond. Le taux de succès des interventions pour cholélithiase se compare à celui de la sphinctérotomie endoscopique chez les patients qui ont moins de trois calculs de moins d'un centimètre de diamètre. La plupart des études ont fait état d'un nombre moindre de complications après la dilatation par ballonnet qu'après la sphinctérotomie endoscopique. Une étude, par contre, a fait état d'une incidence plus élevée de pancréatite et en particulier, de pancréatite grave. Par conséquent, on note toujours une certaine réticence de la part des endoscopistes à promouvoir la dilatation par ballonnet comme intervention à effectuer d'emblée. Or, cette technique est acceptée comme traitement de choix chez les patients qui ont une tendance hémorragique et chez ceux dont l'anatomie est associée à un risque accru de complications dans l'éventualité d'une sphinctérotomie endoscopique. Ces patients sont notamment ceux qui souffrent d'un diverticule périampullaire ou ayant subi une opération de Billroth II.
E ndoscopic sphincterotomy (EST) and stone extraction were introduced in 1973 (1). It is estimated that approximately 150,000 sphincterotomies are performed annually in the United States, in the majority of cases to allow removal of bile duct stones.

Endoscopic balloon dilation (EBD) of the biliary sphincter to allow extraction of bile duct stones was first described by Staritz et al (2) in 1983. However, further development of endoscopic balloon dilation for stone removal stalled in the mid-1980s, when it was suggested that EBD was associated with an unacceptably high risk for pancreatitis. Although the reports on which this was based concerned patients undergoing EBD for the treatment of sphincter of Oddi dysfunction and did not evaluate EBD as a technique for stone removal, the results were extrapolated and EBD fell into disuse for stone removal as well. It was not until the early 1990s that EBD was revived for the removal of bile duct stones. The introduction of laparoscopic cholecystectomy increased the number of young patients being referred for EST and stone removal. The unknown long term effects of ablation of the biliary sphincter after EST led some endoscopists to reevaluate EBD as a possible alternative. Since then, several uncontrolled series have shown that EBD may allow effective and safe stone removal (3-7).

\section{TECHNIQUE}

EBD can be easily applied after deep cannulation of the bile duct by a diagnostic catheter. A guidewire is then left in the bile duct. Over the guidewire, a dilation balloon catheter of $8 \mathrm{~mm}$ diameter and $3 \mathrm{~cm}$ length can be positioned through the sphincter of Oddi. The balloon can be inflated manually or by a pressure device with manometer. Diluted contrast is used for filling the balloon. The waist in the balloon disappears at fluoroscopy when filling the balloon under pressure. Never more than $405.3 \mathrm{kPa}$ pressure should be applied. Once the waist has disappeared, the balloon can be emptied and

Department of Gastroenterology and Hepatology, Academic Medical Center, University of Amsterdam, Amsterdam, The Netherlands

Correspondence: Prof Dr K Huibregtse, Department of Gastroenterology and Hepatology, Academic Medical Center, University of Amsterdam, PO Box 22700, 1100 DE Amsterdam, The Netherlands. Telephone 31-20-566-5908, fax 31-20-691-2985, e-mail k.huibregtse@amc.uva.nl 
removed. The stones are then removed with a dormia basket or balloon catheter. Large concrements should first be fragmented by lithotripsy. Cannulation of the bile duct after EBD may be difficult in some patients. It is imperative that the wound of the EBD is not excessively traumatized by forcefully pushing the dormia basket or other device. The papilla is wide open after EBD, and cannulation should be easy when the opening is gently probed by the different devices.

\section{RESULTS}

To compare the results and complications of EBD and EST, randomized trials are imperative. Two of these studies have been completed. One is the Amsterdam single-centre study (8), and the other is the American multicentre study, which has only been published in abstract form (9).

In the Amsterdam study, stones of all sizes were completely removed in a single endoscopic session in $89 \%$ of EBD patients. The success rate of EBD was comparable with that of standard EST and stone extraction. However, mechanical lithotripsy was required more often after EBD than after EST. When Bergman et al (8) looked into the subgroup of patients with small stones and fewer than three stones, their results and those of the American study were comparable (98\% and 100\%). The lesson to be learned from these series is that, in patients with smaller and fewer bile duct stones, EBD nearly always allows successful stone removal. In patients with larger or multiple stones, the bile duct can be successfully cleared in the majority of patients after EBD, but lithotripsy is required in about $50 \%$ of patients and an additional sphincterotomy or repeat endoscopic retrograde cholangiopancreatography is needed in $15 \%$ to $30 \%$ of patients. With comparable success rates, the choice between EBD and EST should, therefore, be based on the rate of complications, and on the relative efforts and costs of the two procedures.

\section{COMPLICATIONS}

In the Amsterdam study, the rate of early complications after EBD was lower than that after EST (17\% versus $24 \%)$. The difference, however, was not statistically different. No significant bleeding was observed after EBD in over 550 reported patients. Therefore, EBD is particularly suitable for patients with an increased risk of bleeding.

In the study by Bergman et al (8), 7\% pancreatitis was observed in both the EBD and the EST groups. In the 550 reported patients, the overall pancreatitis rate was $5.7 \%$. In the American study, the pancreatitis rate was $11 \%$, with four cases of severe pancreatitis, of whom two died.

Several differences between the Amsterdam and the American study may shed light on this difference in pancreatitis rate. The mean age of the patients differed substantially (Amsterdam 72 years; American 45 years). Because age is an independent risk factor for the development of post-ERCP pancreatitis, the difference in pancreatitis rates may be a re- sult of the selection of patients. It is, however, important to realize that the younger study population had exactly the characteristics that, in theory, make it the most suitable population for EBD - patients with smaller bile duct stones that allow for easy and effective stone removal after EBD and patients of a relatively young age who can benefit most from the preservation of sphincter function.

The results of the American study may better reflect the results and complications of EBD in practice. The Amsterdam study was performed by very experienced endoscopists, whereas the multicentre American study was performed by endoscopists with different levels of experience. Furthermore, there is a learning curve associated with EBD, and some centres contributed only a few patients to the entire study.

\section{WHAT IS THE CURRENT STATUS OF EBD?}

The theoretical advantage of sphincter preservation after EBD, which is particularly applicable to young patients, is thought by many endoscopists to be outweighed by the suggested increased risk of pancreatitis. The presence of risk factors for bleeding seems to be a clear-cut indication for EBD. In addition, EBD is a valid and may be a more safe option in patients in whom the local anatomy makes a sphincterotomy more risky or impossible - for example patients with periampullary diverticula or Billroth II gastrectomy (10). Further studies may show EBD to be indicated in a wider range of patients.

\section{REFERENCES}

1. Classen M, Demling L. Endoskopische sphinkterotomie der papilla vateri und steinextraktion aus ductus choledochus. Dtsch Med Wochenschr 1974;99:496-7.

2. Staritz M, Ewe K, Meyer zum Buschenfelde KH. Endoscopic papillary dilatation (EPD) for the treatment of common bile duct stones and papillary stenosis. Endoscopy 1983;15:197-8.

3. Mathuna PM, White P, Clarke E, Merriman R, Lennon JR, Crowe J. Endoscopic balloon sphincteroplasty (papillary dilatation) for bile duct stones: efficacy, safety, and follow-up in 100 patients. Gastrointest Endosc 1995;42:468-74.

4. Minami A, Nakatsu T, Uchida N, et al. Papillary dilatation vs sphincterotomy in endoscopic removal of bile duct stones. Dig Dis Sci 1995;40:2550-4.

5. Prat F, Boyer J, Pelletier G, et al. Endoscopic sphincteroclasy for choledocholithiasis. Gastroenterology 1996;110:A473. (Abst)

6. Song SY, Lee DH, Chung JB, et al. Endoscopic removal of common bile duct stones without sphincterotomy. Gastroenterology 1996;110:A476. (Abst)

7. Komatsu Y, Kawabe T, Toda N, et al. Endoscopic papillary balloon dilatation for the management of common bile duct stones: experience of 226 cases. Endoscopy 1998;30:12-7.

8. Bergman JJGHM, Rauws EAJ, Fockens P, et al. Randomised trial of endoscopic balloon dilation versus endoscopic sphincterotomy for removal of bileduct stones. Lancet 1997;349:1124-9.

9. DiSario JA, Freeman ML, Bjorkman DJ, et al. Endoscopic balloon dilatation compared to sphincterotomy (EDES) for extraction of bile duct stones: preliminary results. Gastrointest Endosc 1997;45:A129. (Abst)

10. Prat F, Fritsch J, Choury AD, Meduri B, Pelletier G, Buffet C. Endoscopic sphincteroclasy: a useful therapeutic tool for biliary endoscopy in Billroth II gastrectomy patients. Endoscopy 1997;29:79-81. 


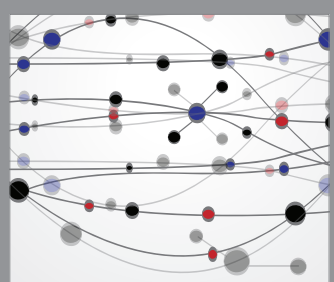

The Scientific World Journal
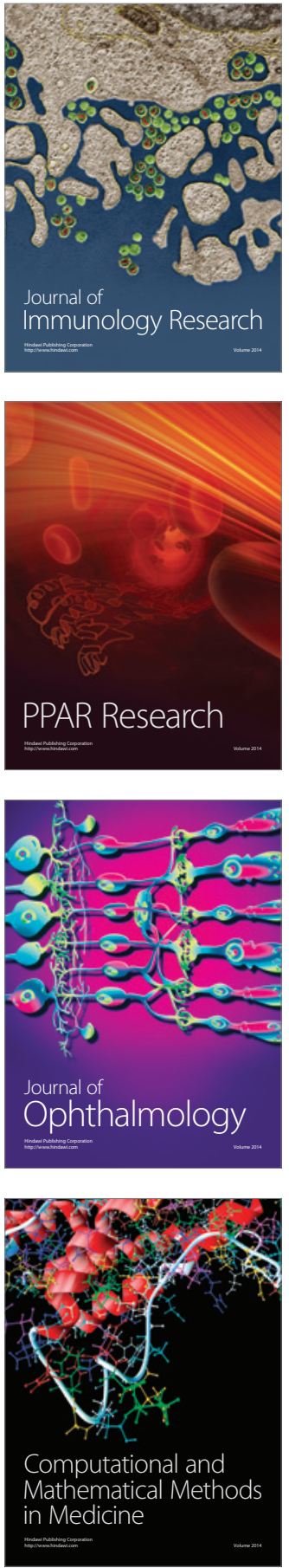

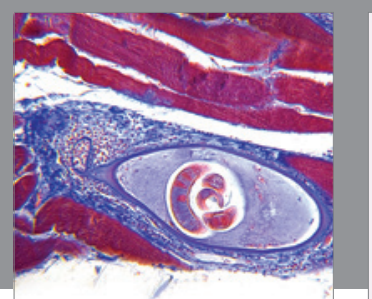

Gastroenterology Research and Practice

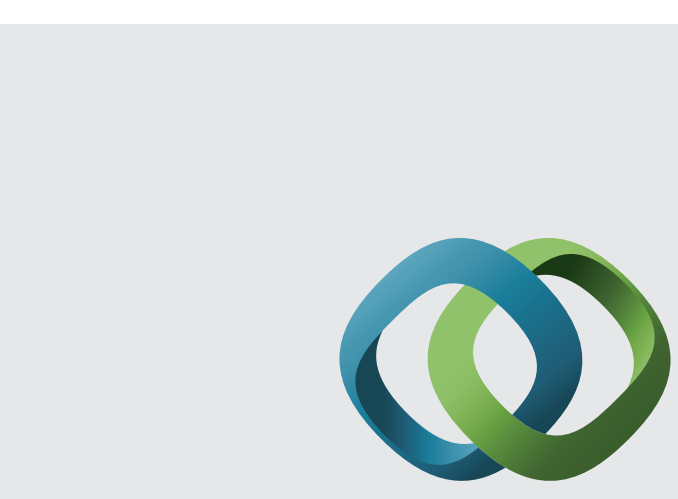

\section{Hindawi}

Submit your manuscripts at

http://www.hindawi.com
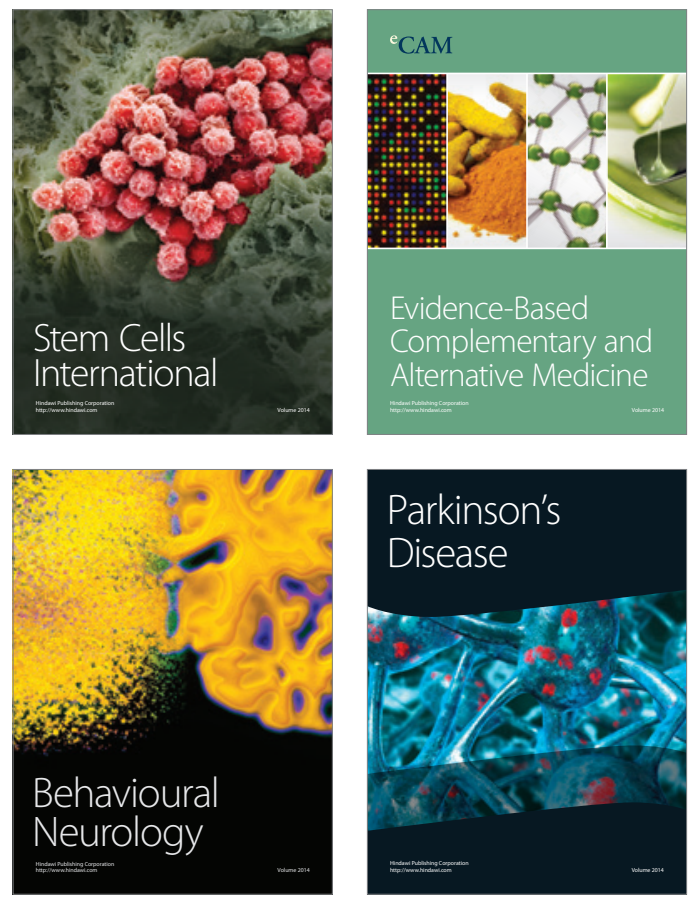
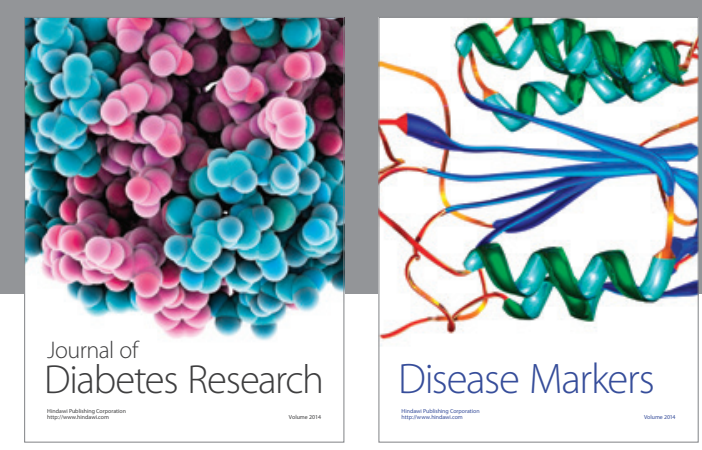

Disease Markers
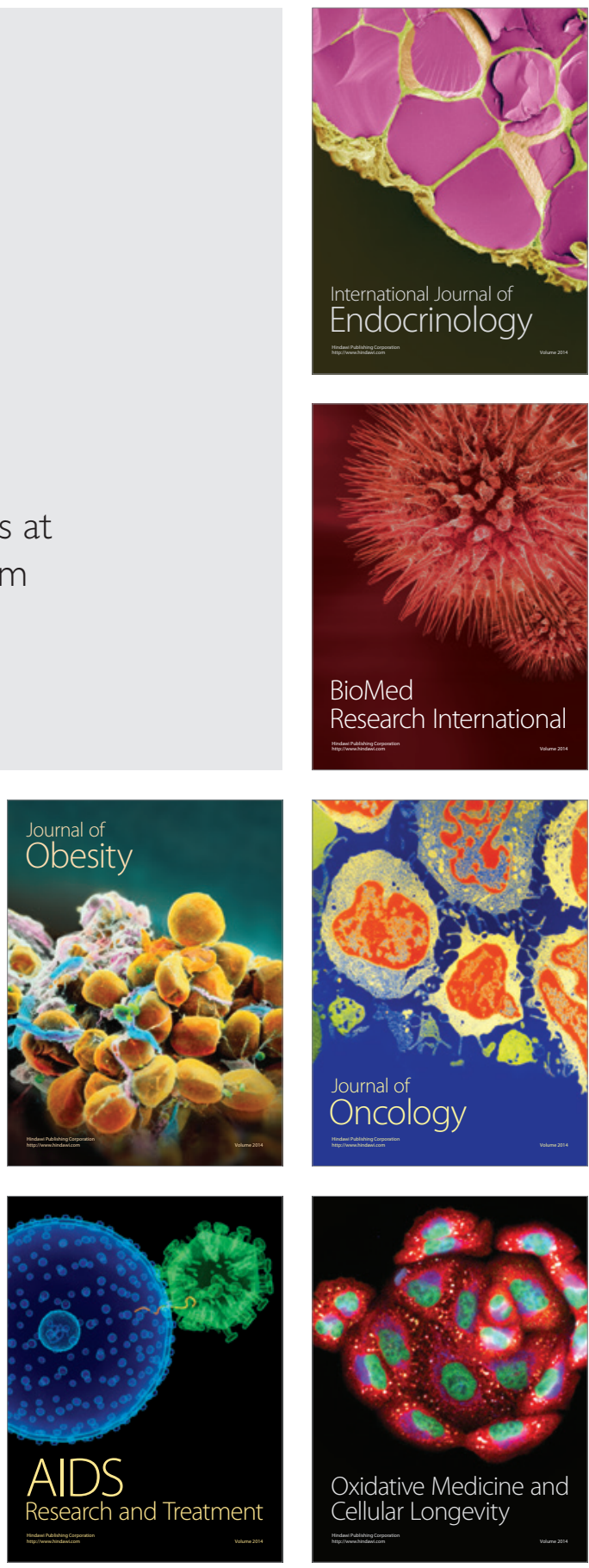